\title{
THE FISHERY FOR SPECKLED TROUT, Salvelinus fontinalis, OVER A 28 YEAR PERIOD IN THE TANGIER GRAND LAKE WILDERNESS AREA, NOVA SCOTIA
}

\author{
JOHN L. MACMILLAN*, REGINALD J. MADDEN, \\ TAMARA WILSON and MEGAN KENNY \\ Inland Fisheries Division, \\ Nova Scotia Department of Fisheries and Aquaculture, \\ Box 700, Pictou, Nova Scotia BOK 1 HO
}

\begin{abstract}
The Tangier Grand Lake Wilderness Area (16,000 ha) is located about $100 \mathrm{~km}$ east of Halifax, Nova Scotia, and supports a popular fishery for speckled trout. The purpose of this study was to assess the status of the trout fishery and address concerns related to over-exploitation. Angler check points were occupied during 1979 and 2007 on an access road to sample the catch of anglers during the May-June period of heavy angler activity. In 1979, a total of 1380 interviewed anglers spent 6889 hours to catch 1852 trout. In comparison, a total of 178 interviewed anglers spent 1363 hours to catch 593 trout during 2007. The differences associated with sample size between survey years reflect sub-sampling in 2007 rather than a change in angler activity. The majority of anglers retained less than three trout and of the total trout caught, anglers released 19\% in 1979 and 50\% in 2007. Catch per hour, size, age, and growth rate of trout were similar between surveys. Results indicated that there was little change in this fishery between the 28 years separating the two creel surveys.
\end{abstract}

\section{INTRODUCTION}

Several factors have influenced the Nova Scotia sport fishery over the past 30 years. The number of licensed anglers in Nova Scotia has declined by approximately thirty five percent since the 1970s. Coincidentally, as one would expect, angler catches have also declined in many areas; however, the decline in the total speckled trout, Salvelinus fontinalis, catch has occurred at a greater rate than the decline in the number of anglers in the province. Introduction of invasive species, habitat loss and over-exploitation can all influence trout populations 
and angler catches (MacMillan and Madden, 2007, NSDFA 2005). Regional differences in habitat condition may also influence the health of trout populations. For example, the Tangier Grand Lake Wilderness Area (TGLWA) is located in eastern Nova Scotia where freshwaters tend to be nutrient poor, acidic and sensitive to warming, whereas the geology in the Northern Mainland and Cape Breton provides cooler water in summer and in many areas there is a natural buffering capacity against the impacts of acidity that benefits speckled trout production (MacMillan et al. 2008). Introduction of invasive smallmouth bass, Micropterus dolomieu, and chain pickerel, Esox niger, have occurred to a much lesser extent in waters of the Northern and Eastern Nova Scotia (McNeill, 1995). Generally, speckled trout are considered to be poor competitors to most freshwater fish in Nova Scotia and this is especially true in marginal habitats (Hayes and Livingstone, 1955, Alexander 1975, Alexander et al. 1986). Quinn et al. (1994) demonstrated that trout production was related to the presence of other fish species in lakes in Ontario. The compounding influences of exploitation and habitat losses on trout has often been cited as allowing other populations of fish species to increase and eventually dominate the habitat of lakes and streams (Smith 1938, 1940, Browne and Rasmussen 2009, Munro and MacMillan 2012). Nova Scotia has made regulatory changes to reduce exploitation on the speckled trout resource including a reduction in the daily bag limit from 15 to 5 , as well as a change from a retention season to a release season during September (Inglis 1995).

Many sport fisheries are influenced by over-exploitation (Post et al. 2002). Anglers, environmental organizations and fishery managers have become more interested in changing regulations to improve fisheries and conserve stocks in light of these trends. Further, some studies suggest that exploitation could influence genotypes for aggression and growth rates on targeted populations (Biro and Post 2008). Curry et al. (2003) estimated total fishing mortality at $44 \%$ on a speckled trout population in Meach Lake, Ontario, and recommended that fishing mortality should not exceed that level in other lakes.

Recently, eastern NS anglers at the public Recreational Fishing Advisory Council meetings provided input concerning the poor status of trout fisheries and the need for new regulations. Interest was expressed in designating the entire TGLWA a Special Trout Management Area where regulations could be implemented in an attempt to reduce harvest and improve the sport fishery for speckled trout. Sabean (1980) and 
Heggelin (2008) suggested that angling pressure could be influencing the status of trout populations in lakes of the TGLWA. Sabean (1980) reported that Egg Lake was potentially overfished. While studying 12 lakes within the TGLWA, Heggelin (2008) demonstrated that the presence of larger trout was correlated with less angling activity. Conversely, Halfyard et al. (2008) suggested that exploitation was not an important factor regulating trout populations in three interior TGLWA lakes.

In response to concerns expressed by anglers, the Inland Fisheries Division agreed to conduct an angler creel survey in the same region that was studied 28 years prior. The objective of this study was to assess the degree of change that may have occurred in the TGLWA fishery and whether there was a need for new regulations to reduce harvest.

\section{METHODS AND STUDY AREA}

The results from an extensive creel survey in the Mooseland Region, Halifax County, carried out in 1979 (Sabean 1980) provided baseline data for the fishery in TGLWA. The southern portion of the Mooseland to Murchyville road borders the TGLWA which includes 16,000 hectares that have been designated under the Nova Scotia Protected Areas Program.

The majority of the forest in the region is dominated by spruce, pine, fir, and occasionally hemlock. Red maple and yellow birch occur in areas of richer, deeper soils. This landscape was formed approximately 10,000 years ago by a receding glacier that scoured out numerous depressions which are now occupied by about 100 lakes and numerous streams. The geological makeup of this region includes mainly shallow soil cover over granite and greywacke and supports relatively unproductive waters that tend to be acidic (Davis and Brown 1996). Heggelin (2008) reported mean $\mathrm{pH}$ values ranged from 4.6 to 5.3 from twelve lakes in the TGLWA. Fish species that are considered to be competitors of speckled trout in some lakes within the TGLWA and surrounding region include yellow perch, Perca flavecsens, white sucker, Catostomus commersoni, brown bullhead,Ameiurus nebulosus, and American eel, Anquilla rostrata (Alexander et al. 1986).

The 2007 creel survey followed the methods used during 1979 (Sabean 1980). In 1979, anglers were interviewed as they exited a 30 $\mathrm{km}$ gated road that runs from Murchyville to Mooseland. The 2007 
survey was shorter as the sampling period was from 6 May to 10 June compared to 1 May to 30 June in the 1979 survey. Sampling days during the recent survey were mainly on weekends and holidays. During the 1979 creel survey, angler check points were set up at both Murchyville and Mooseland Road exits whereas in 2007, only the Murchyville exit was sampled regularly (Fig 1). In 2007, a sign was placed beside the exit providing notice to anglers of the voluntary creel survey. While the majority of anglers provided information to creel clerks, some refused to participate.

On a number of occasions during the 2007 survey, a roving creel survey was conducted in order to gather information from additional anglers within TGLWA. On the 21 May, officers from Fisheries and Oceans, Nova Scotia Department of Natural Resources and Nova Scotia Department of Environment and Labour were involved in a cooperative enforcement patrol and angler survey. Angler surveys were conducted at check points on the Fish River Bridge as well as the Mooseland exit. Cool temperatures during the 21 May enforcement check may have resulted in relatively few anglers available for interviews. Creel data were sampled from anglers who collectively reported fishing at twenty-

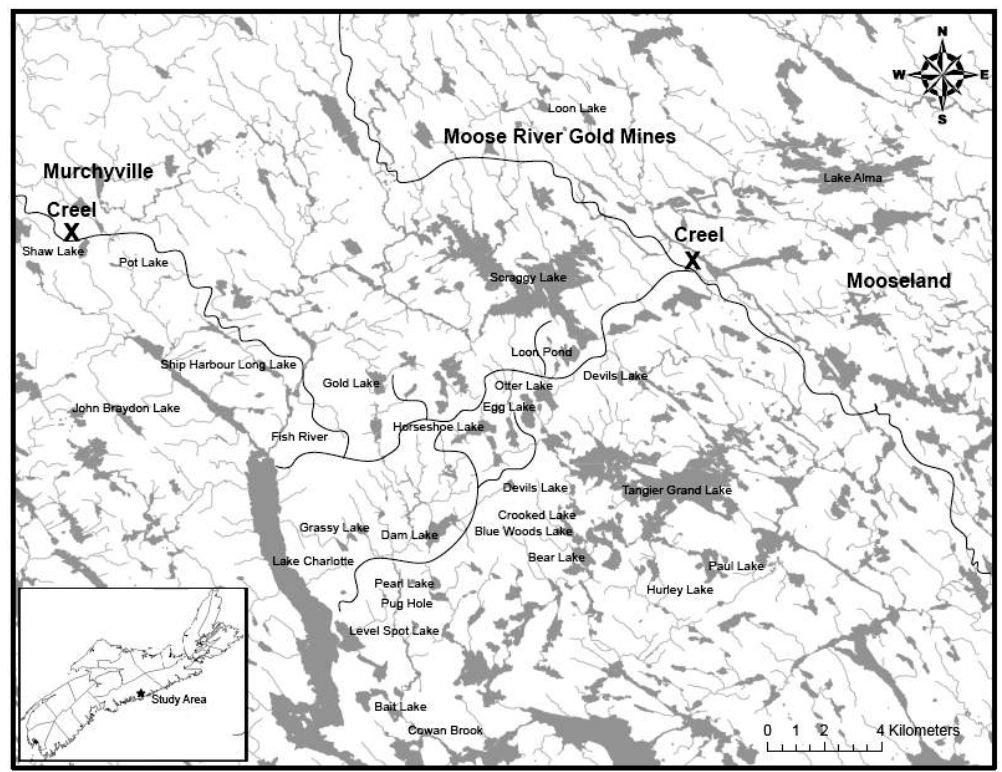

Fig 1 Mooseland to Murchyville creel survey sites and the lakes that were targeted by anglers in 1979 and 2007. 
five locations; 22 lakes, Cowan Brook, Butler Lake still water, and Fish River. Data from Pug Hole Lake and Pearl Lake were combined as a number of anglers reported fishing from both during one angling trip.

Creel data included size of the catch, time spent angling, residence of the angler, site fished, gear type, species caught, and the collection of fish scales for aging. Catch per unit effort (CPUE) was presented in terms of trout caught per hour of angling. Trout harvested by anglers were measured for fork length (FL, mm). Commonly, anglers cleaned their catch prior to participating in the creel survey. Cleaned trout were measured and if heads were removed, the presence or absence of pectoral fins was recorded. If the pectoral fins were removed, an additional $35 \%$ of the length was added to approximate FL. If the pectoral fins were present, an additional $30 \%$ was added. These additions to length were incorporated into the study so that estimations of FL would remain consistent with the 1979 study. The proportions of large trout $(\mathrm{FL}>30 \mathrm{~cm})$ in the catch were compared with the 1979 data set (z-test).

Scales were sampled from the area on the body between the lateral line and dorsal fin. Scales were aged by two readers. If no agreement was reached, a third reader was used and a consensus for each age was reached. Mean length at age was calculated for most of the trout populations sampled.

Site specific comparisons of FL and CPUE (retained and total) were made for eight of the surveyed sites; Egg Lake, Fish River, Grassy Lake, Lake Charlotte, Level Spot Lake, combined Pearl \& Pug Hole Lakes, Ship Harbour Long Lake, and Loon Lake (Fig 1). Data sets from Loon Lake, Egg Lake, and Level Spot Lake were supplemented by additional angling and gill netting by staff of the Inland Fisheries Division. Catch rates from the 1979 survey were only based on retained trout whereas catch rates for released trout, retained, and total trout caught were available from individual records in the 2007 survey. Total trout CPUE was estimated for 1979 sites based on the average release rate of 19\% reported (Sabean 1980). The total (retained and released) trout CPUE was calculated for 2007. Differences between surveys for mean size of the catch, CPUE, and length at age of speckled trout were compared using t-tests $(\mathrm{P}<0.05)$. 


\section{RESULTS}

The mean distance travelled by anglers to Murchyville was $58 \mathrm{~km}$ (28 SD). The majority $(60 \%)$ of the anglers interviewed during the 2007 Mooseland to Murchyville creel survey resided in the communities of Dartmouth/Halifax/Sackville, Enfield and Truro. The distance from Murchyville was $42 \mathrm{~km}$ from Enfield and approximately $60 \mathrm{~km}$ from Dartmouth/Halifax/Sackville and Truro. One angler interviewed was from Moncton, New Brunswick, an estimated $221 \mathrm{~km}$ from Murchyville. The remainder was from small communities, most of which was located within a $60 \mathrm{~km}$ radius of the creel survey check point at Murchyville. In 2007, a total of 178 anglers interviewed spent 1363 hours and 284 days to catch 593 trout. In comparison, a total of 1380 anglers interviewed spent 6889 hours and 2085 days to catch 1852 trout in 1979. As expected, the number of angler hours found during weekends in 2007 was less compared to the 1979 survey.

Most angling hours were spent fishing on Fish River, Ship Harbour Long Lake, Paul Lake, Gold Lake, Bait Lake, Bear Lake, and Dam Lake. The number of angling hours recorded on each site ranged from four hours on Blue Woods Lake to 194 hours on Fish River. The mean release rate during 2007 by lake was $0.38( \pm 0.31, \mathrm{SD})$ when all sites were included and the average overall release rate based on the total retained trout compared to the total released was 0.50 of the total catch. The average release rate reported for 1979 was 0.194 (Sabean 1980), indicating that anglers are releasing a much greater proportion of their catch than in the past. During 2007, the total (retained and released) number of trout caught per hour of angling per site was variable and the overall mean CPUE per lake was $0.64( \pm 0.69, \mathrm{SD})$ and ranged from 0 to 2.8 trout. The mean number of trout caught per individual angler was 4.0 trout $( \pm 4.2, \mathrm{SD})$ and ranged from $0-17$ caught per angler per site (Table 1).

Creel statistics were compared for eight sites between the 1979 and 2007 surveys. During 2007, mean FL of retained trout was $25 \mathrm{~cm}$ $( \pm 3.3, \mathrm{SD})$ and ranged from $20-31 \mathrm{~cm}$ compared to $24.9 \mathrm{~cm}( \pm 1.9$, SD) and a range of $22-28 \mathrm{~cm}$ in 1979. During 2007, the number of trout caught per hour was $0.62( \pm 0.6, \mathrm{SD})$ and ranged from 0.04 to 1.56 . During 1979 the CPUE was $0.50( \pm 0.2, \mathrm{SD})$ and ranged from 0.20 to 0.78 (Table 2). No significant difference was detected between mean FL and CPUE between surveys (t-test, $\mathrm{P}>0.05$ ). The increased variability in the 2007 data was expected, given the smaller sample size. 


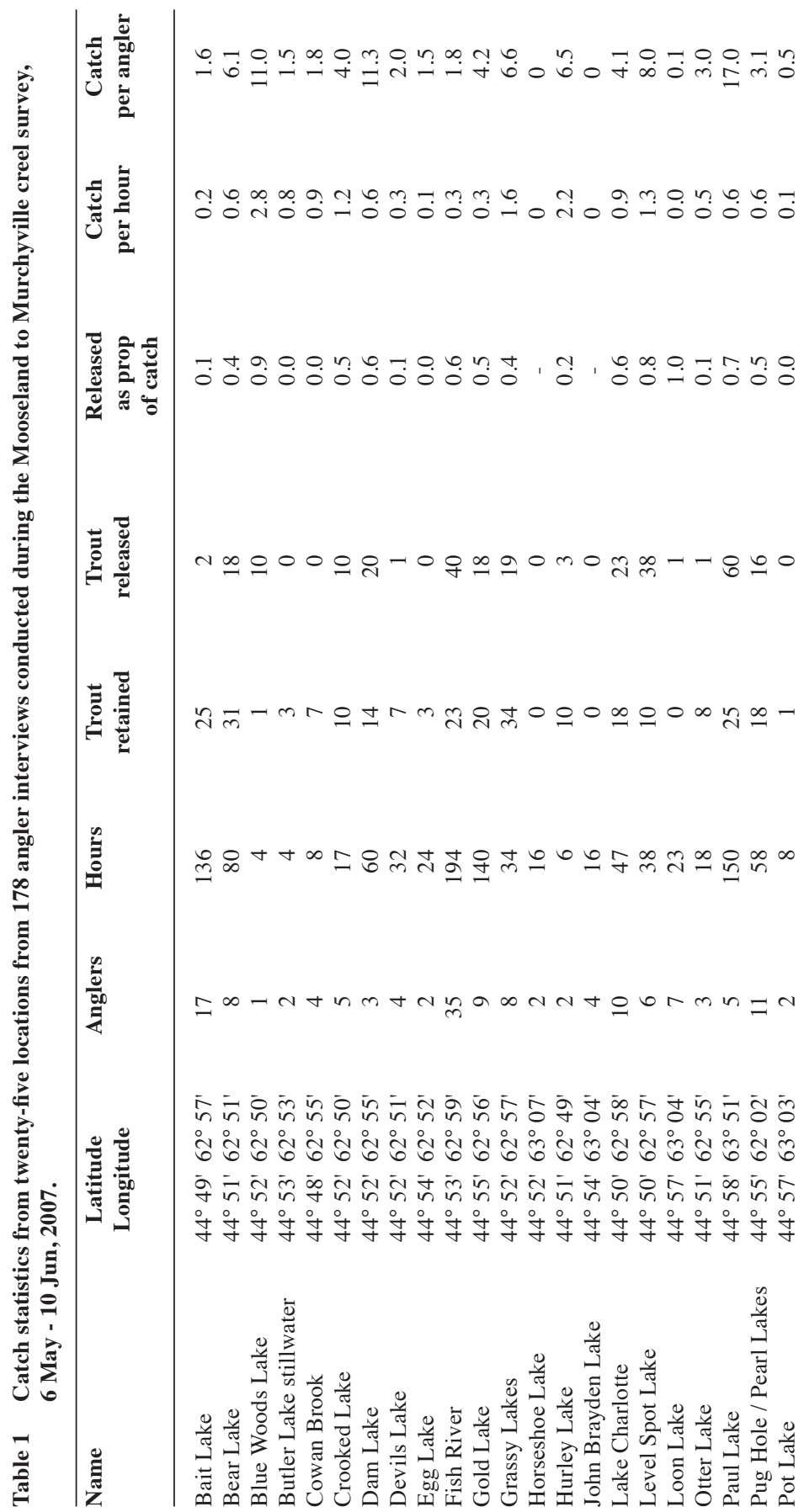




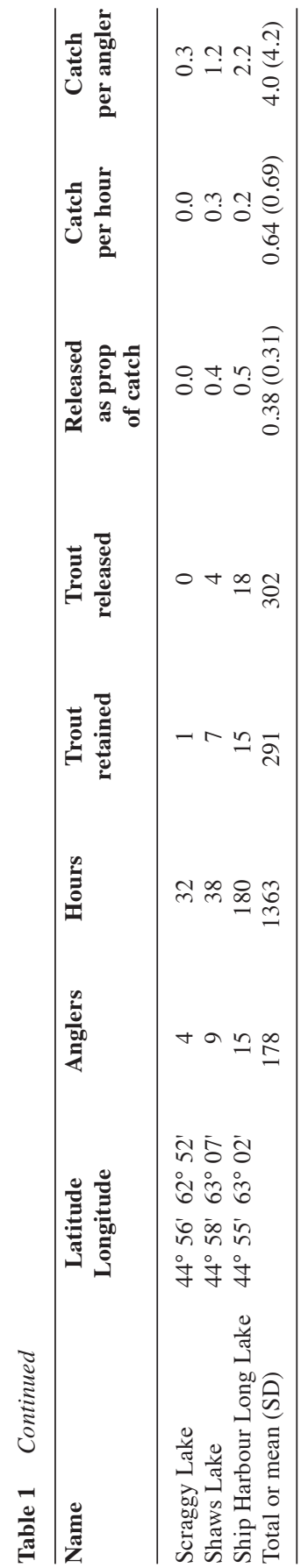

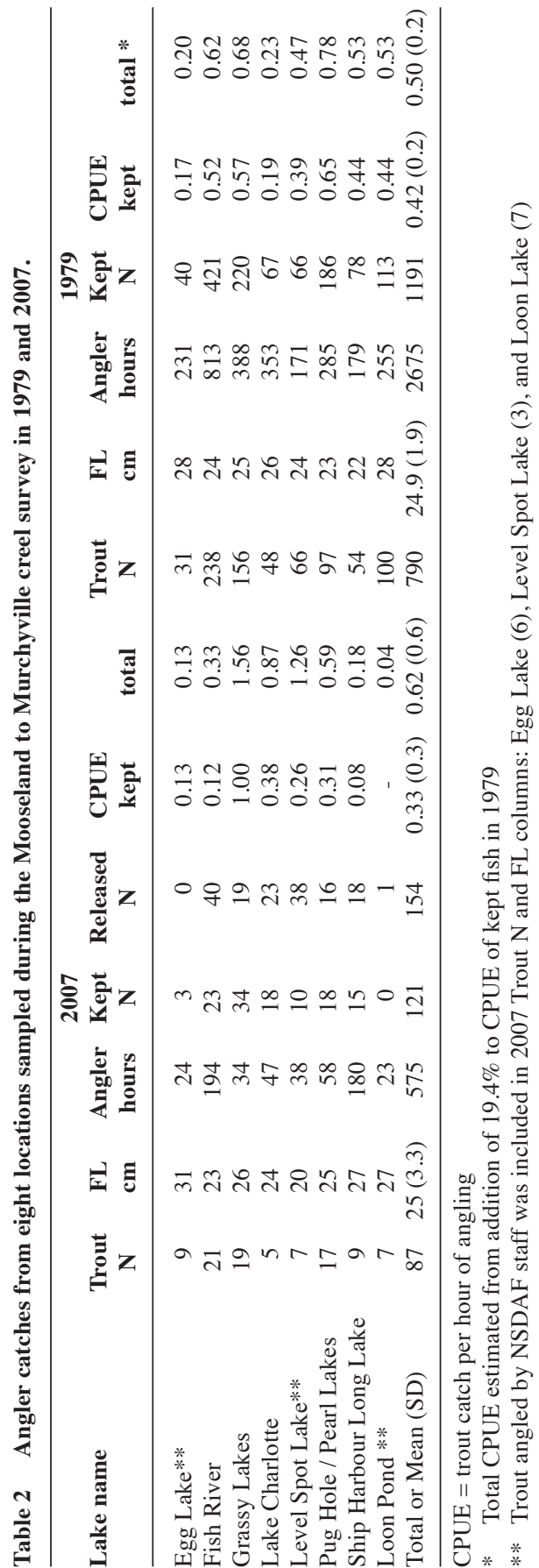




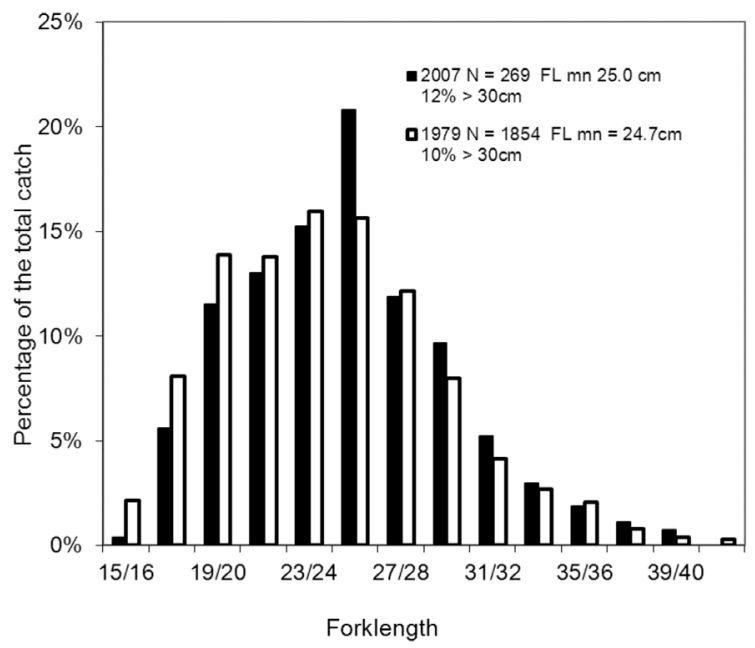

Fig 2 Fork length $(\mathrm{cm})$ frequency distributions of the speckled trout catch from anglers interviewed during the Mooseland to Murchyville creel surveys in 1979 and 2007.

Change in catch size structure, and particularly in the proportion of larger fish, may reveal disturbances to the population, affecting mortality. The relative proportion of large trout $(>30 \mathrm{~cm}$ FL) in the catch was 0.10 in 1979 and 0.12 in 2007 (Fig 2). The data indicate that the mean FL of speckled trout caught by anglers and the CPUE were similar between surveys and no significant difference was detected in the proportion of large trout $(\mathrm{FL}>30 \mathrm{~cm})$ captured between the two surveys ( $\mathrm{z}$-test, $\mathrm{P}=0.367$ ).

In 2007, mean FL at age from eighteen lakes and Fish River was $22.4 \mathrm{~cm}( \pm 2.1, \mathrm{SD})$ for $2+\mathrm{y}$ trout $(18.8-25.7 \mathrm{~cm}), 27.7 \mathrm{~cm}( \pm 2.7, \mathrm{SD})$ for $3+y$ trout $(21.6-33.5 \mathrm{~cm})$, and was $34.9 \mathrm{~cm}( \pm 3.0, \mathrm{SD})$ for $4+\mathrm{y}$ trout $(31.5-38.9 \mathrm{~cm})$. In 1979, mean FL at age was available from Scraggy Lake, Pug Hole/Pearl Lake, Fish River, and Lake Charlotte. During 1979, mean FL was $21.5 \mathrm{~cm}( \pm 1.7, \mathrm{SD})$ for $2+y$ trout $(20.4-22.7$ $\mathrm{cm}), 27.8 \mathrm{~cm}( \pm 2.4, \mathrm{SD})$ for $3+y$ trout $(24.8-30.4 \mathrm{~cm})$, and was 33.1 $\mathrm{cm}( \pm 2.4, \mathrm{SD})$ for $4+\mathrm{y}$ trout $(30-36.1 \mathrm{~cm})$ (Table 3). No significant differences were detected for mean FL of trout at ages 2+, 3+, and 4+ $y$ between the two surveys (t-test, $P>0.05$ ).

The age structure of the catch indicated that the majority of the trout caught by anglers were from the $2+$ and $3+$ age classes. Few $4+y$ trout were detected and $1+\mathrm{y}$ and $5+\mathrm{y}$ trout were absent from the samples 
Table 3 Mean length at age of the trout catch from eighteen lakes and two stream systems from anglers interviewed during the Mooseland to Murchyville creel survey, 1979 and 2007.

\begin{tabular}{|c|c|c|c|c|c|c|c|c|c|c|}
\hline \multirow{2}{*}{$\begin{array}{l}\text { Year } \\
\text { years }\end{array}$} & \multirow[t]{2}{*}{ Name } & \multicolumn{3}{|c|}{ Age 2+ years } & \multicolumn{3}{|c|}{ Age $3+$ years } & \multicolumn{3}{|c|}{ Age 4+ } \\
\hline & & $\mathbf{N}$ & FL & SD & $\mathbf{N}$ & FL & SD & $\mathbf{N}$ & FL & SD \\
\hline \multirow[t]{21}{*}{2007} & Bait Lake & 7 & 22.1 & 2.4 & 17 & 27.2 & 2.7 & & & \\
\hline & Bear Lake & 3 & 25.7 & 0.8 & 18 & 29.8 & 2.1 & & & \\
\hline & Blue Woods Lake & & & & 1 & 33.5 & & & & \\
\hline & Cowan Brook & 6 & 21.9 & 1.6 & 1 & 26.5 & - & 1 & 38.9 & - \\
\hline & Crooked Lake & 2 & 25.7 & 3.1 & 8 & 29.2 & 4.2 & 3 & 36.4 & 2.4 \\
\hline & Dam Lake & 10 & 21.0 & 1.7 & 2 & 21.6 & 0.5 & & & \\
\hline & Devils Lake & 3 & 24.2 & 0.8 & 3 & 28.5 & 2.5 & & & \\
\hline & Egg Lake & 13 & 19.5 & 3.6 & 7 & 31.0 & 3.9 & 1 & 32.4 & - \\
\hline & Fish River & 19 & 21.0 & 2.2 & 9 & 25.0 & 1.7 & & & \\
\hline & Gold Lake & 8 & 22.1 & 1.3 & 3 & 24.1 & 2.8 & & & \\
\hline & Grassy Lake & 7 & 22.9 & 1.5 & 11 & 27.4 & 3.7 & & & \\
\hline & Hurley Lake & & & & 9 & 29.2 & 2.2 & 1 & 31.5 & \\
\hline & Lake Charlotte & 4 & 20.9 & 1.9 & & & & 1 & 35.4 & \\
\hline & Level Spot Lake & 9 & 18.8 & 1.9 & & & & & & \\
\hline & Loon Lake & 17 & 20.2 & 1.7 & 5 & 28.6 & 1.2 & & & \\
\hline & Otter Lake & 4 & 23.0 & 2.0 & 4 & 27.5 & 2.1 & & & \\
\hline & $\begin{array}{l}\text { Pug Hole/ } \\
\text { Pearl Lakes }\end{array}$ & 11 & 24.3 & 1.1 & 7 & 26.2 & 2.0 & & & \\
\hline & Scraggy Lake & & & & 1 & 29.7 & & & & \\
\hline & Shaws Lake & 1 & 23.0 & - & 7 & 26.1 & 1.4 & & & \\
\hline & $\begin{array}{l}\text { Ship Harbour } \\
\text { Long Lake }\end{array}$ & 3 & 24.6 & 1.8 & 6 & 28.2 & 3.9 & & & \\
\hline & Summary & 127 & 22.4 & 2.1 & 119 & 27.7 & 2.7 & 7 & 34.9 & \\
\hline \multirow[t]{5}{*}{1979} & Scraggy Lake & 17 & 22.7 & 1.7 & 83 & 29.3 & 3.5 & 17 & 36.1 & 3.7 \\
\hline & Fish River & 27 & 20.4 & 2.2 & 22 & 24.8 & 2.4 & 1 & 30.0 & \\
\hline & Pug Hole/ Pearl Lakes & 2 & 20.5 & 3.5 & 12 & 26.5 & 1.2 & & & \\
\hline & Lake Charlotte & 6 & 22.4 & 2.1 & 6 & 30.4 & & & & \\
\hline & Summary & 52 & 21.5 & 1.7 & 123 & 27.8 & 2.4 & 18 & 33.1 & 2.4 \\
\hline
\end{tabular}

from 1979 and 2007 (Fig 3). Age structure information was available for comparison among three sites surveyed in 1979 and included Pug Hole/Pearl Lake, Lake Charlotte, and Fish River. When these age structure data were pooled the proportion in each year class was 0.46 for $2+y, 0.53$ for $3+y$, and 0.01 for $4+y$ trout in 1979 , and was 0.67 for $2+\mathrm{y}, 0.31$ for $3+\mathrm{y}$ and 0.02 for $4+\mathrm{y}$ in 2007. A significant difference was detected in the proportion of $2+$ and $3+y$ trout captured between surveys ( $\mathrm{z}$-Test, $\mathrm{P}<0.05)$, but the age structure data were not significantly different when 1979 data from PugHole/Pearl Lake, Lake Charlotte, and Fish River were compared to the total age structure data from 2007 (z-test, $\mathrm{P}>0.05$ ). The age structure of trout caught from Scraggy Lake was also available for comparison from the 1979 survey, however, the data were excluded as only two anglers with one trout were surveyed 


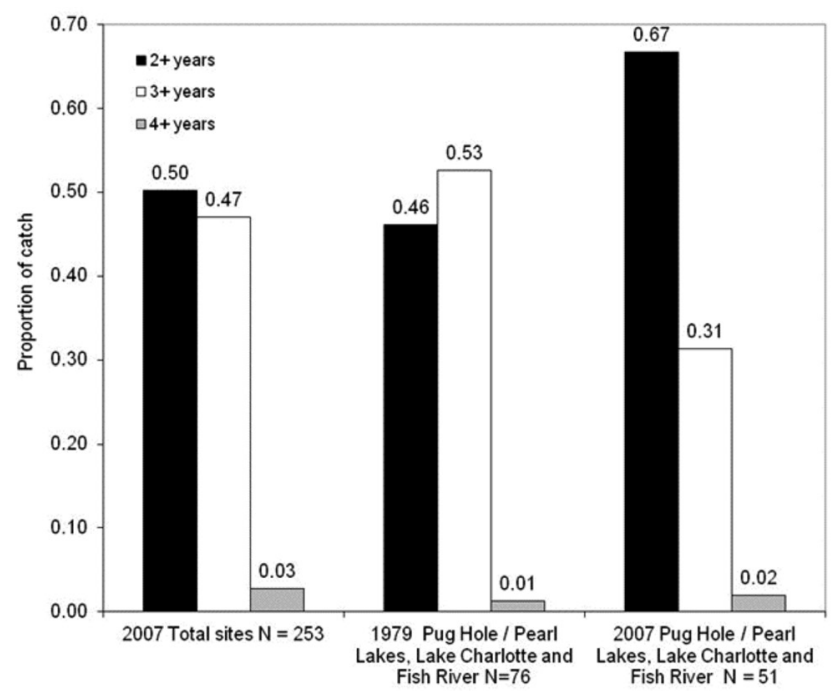

Fig 3 Age structure (y) of the speckled trout catch from anglers interviewed during the Mooseland to Murchyville creel survey, 1979 and 2007.

from this site in 2007. Scraggy Lake was located relatively close to the Mooseland exit and limited time was spent sampling in this location during 2007.

While angling, the most popular gear type used was bait or a combination of bait with lure or fly. The proportion of the CPUE using bait or combination of bait alone or bait with lure or fly remained relatively unchanged between the two surveys; 0.87 in 1979 and 0.88 in 2007. Angler effort using fly only was 0.09 in 1979 and 0.11 in 2007. The greatest number of trout caught per hour was accomplished angling with a fly or a combination of fly and bait, shown in both surveys (Table 4).

During 2007, the average number of trout retained by anglers was determined from 178 anglers in 62 angling parties as 1.7 trout and ranged from zero to 6.5 trout. The majority of the parties interviewed $(82 \%)$ retained less than three trout per angler (Fig 4). Three percent of the parties retained more trout than five per angler but they were fishing for more than one day. These anglers did not exceed the possession limit of five trout per angler as they reported consuming some of the trout caught while on their multi-day fishing trip. The five trout possession limit was reached by nine percent of the anglers interviewed. 
Table 4 Gear type used by anglers as a percentage of the total number of angling hours and mean trout catch per hour during the Mooseland to Muchyville creel survey in 1979 and 2007, Nova Scotia.

\begin{tabular}{lcccc}
\hline & $\begin{array}{c}\text { 1979 } \\
\text { Percentage of effort }\end{array}$ & CPUE & $\begin{array}{c}\text { 2007 } \\
\text { Percentage of effort }\end{array}$ & CPUE \\
\hline Bait & $68 \%$ & 0.46 & $26 \%$ & 0.38 \\
Bait / Fly & $11 \%$ & 0.53 & $35 \%$ & 0.88 \\
Bait / Lure & $5 \%$ & 0.35 & $26 \%$ & 0.57 \\
Bait / Lure / Fly & $4 \%$ & 0.23 & $0.2 \%$ & 0.33 \\
Fly & $9 \%$ & 0.50 & $11 \%$ & 1.02 \\
Lure & $4 \%$ & 0.31 & $1 \%$ & 0.21 \\
\hline
\end{tabular}

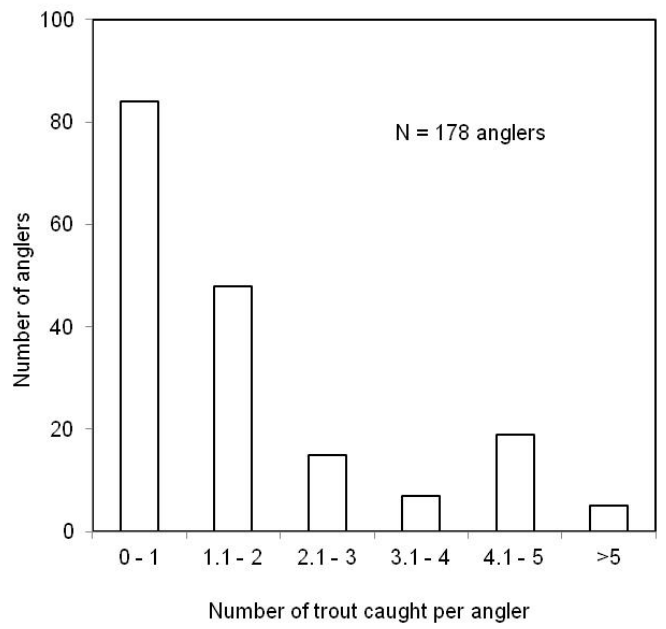

Fig 4 The number of speckled trout retained by 178 anglers interviewed during the Mooseland to Murchyville creel survey, 6 May - 10 June, 2007. Anglers who reported retaining more than a total of five captured trout were angling more than one day.

\section{DISCUSSION}

Creel survey data that related to angler abundance, angler catch rate, size of the catch and mean FL at age were all similar between the surveys. The sample size of the 2007 survey was smaller than that of the 1979 survey; however, it still represented a sizable angler effort and catch from the study area.

Although the percent of large trout caught between the two surveys did not reflect a change, the overall age structure was not available from the 1979 survey. Age structure information from PugHole/ 
Pearl Lake, Lake Charlotte, and Fish River did indicate a shift in the catch toward more two-year-old trout during 2007. This may represent a trend related to the impact of habitat change and exploitation, however, annual variability among year classes of speckled trout can be large (Platts and Nelson 1988).

Similar to the 1979 survey, daily bag limit was considered to have little direct impact on exploitation. The majority of anglers retained two trout per angler instead of the legal possession limit of five trout per angler. Angler effort and accessibility can apparently be more important than angling regulations on trout fisheries (Post et al. 2003). Since the total number of anglers in Nova Scotia has decreased by about $35 \%$ from a high of $85 \mathrm{k}$ in the late 1970 s to about $55 \mathrm{k}$ in the $2000 \mathrm{~s}$ (NSDFA 2000), direct comparison of angler activity in the Mooseland to Murchyville area was difficult to assess. Compared to the results of the 1979 survey, fewer overall angler hours were detected during weekends, but since only one of the two exits were sampled, this difference was anticipated and overall this region continues to be viewed as a popular destination for anglers. The recent wilderness designation of the TGLWA has reduced the ease of angler access into many of the inner lakes as vehicle traffic, mainly with all terrain vehicles, has been restricted. Remote regions of Wilderness Areas may receive less pressure than in the past because of these regulations. Restrictions to land use, in terms of forestry and other development associated with angling and hunting camps, may further reduce the potential for heavy exploitation to occur on some lakes.

On average, anglers interviewed during the 1979 creel survey released about $19 \%$ of their catch compared to an average release rate of $50 \%$ during the 2007 survey. This finding is in agreement with results from surveys conducted every five years which indicate that trout anglers released $26 \%$ of their catch in 1980 compared to $61 \%$ of their catch in 2000 in Nova Scotia (NSDFA 1995, NSDFA 2000). This change in angler behavior has probably reduced the impact of angling activity on exploited trout populations.

Anglers have often expressed a concern about high grading of catches and its impact on trout populations. Angling in general may select for faster growing, more aggressive individuals in fish populations (Biro and Post 2008). It has been suggested that high grading may result in slower growth and smaller individual size in targeted sport fish populations. A similar, mean FL at age found between the two surveys that were 28 y apart suggests that the growth rate of trout in the TGLWA 
has not changed significantly. Population density in trout populations is often related to habitat condition and may override selective impacts associated with exploitation in many lakes. Our findings are in agreement with Halfyard et al. (2008) who reported that the levels of harvest on three TGLWA lakes were less than fish yield estimates and low population density was correlated with size and condition of trout. Similarly, Heggelin (2008) demonstrated positive correlations among twelve TGLWA lakes between angler activity indices and catch rates, as well as inverse relationships between catch rates and the size of the catch. Accessible, productive trout habitats potentially receive more directed effort from anglers; however, the size of the catch may be smaller compared to populations at lower densities.

Catch rates can be highly influenced by weather and activity of the fish. Many anglers plan their fishing trips to correspond to the mayfly hatch in lakes. During this time, water temperatures are close to ideal for trout activity and feeding $\left(10-16^{\circ} \mathrm{C}\right)$ (Power 1980). As a result, catch rates can be very high and may not be representative of trout population density in a lake. Limited production of trout combined with their ease of capture under some circumstances remains a concern; however, angling is only one of many factors that may influence a trout fishery. Although a change in the release rate of trout was detected and a change in angler effort was probable, the data suggests that the level of exploitation has not caused a decline in this fishery. The perspectives of anglers are often diverse and research efforts should be undertaken prior to implementing regulatory changes that may impact opportunities. More study is required to further assess populations of trout as well as their competitors in lakes to better understand the role of competition, exploitation, and habitat limitations.

Acknowledgements We thank Rob Cameron and Dave Dauphinee, Nova Scotia Department of Environment and Labour, and Tim Owen, Fisheries and Oceans, for providing advice and collecting data for this study. Funding to employ technicians was made available from Nova Scotia Public Service Commission through the Summer Female Mentorship Program and the Co-operative Employment Program. 


\section{REFERENCES}

Alexander, D.R. (1975). Sport fisheries potential on twenty lakes in the headwaters of the Shubenacadie River System, Nova Scotia. Resources Development Branch, Fisheries and Marine Service, Halifax, Nova Scotia. Technical Report Series No. Mar/T-75-10.

Alexander, D.R., Kerekes, J.J., \& Sabean, B.C. (1986). Description of selected lake characteristics and occurrence of fish species in 781 Nova Scotia lakes. Proc. N. S. Inst. Sci. 36:63-106.

Biro,P.A. \& Post J.R. (2008). Rapid depletion of genotypes with fast growth and bold personality traits from harvested fish populations. Proc. Nat.Acad. Sci. 105:2919-2922.

Browne, D.R. \& Rasmussen, J.B. (2009). Shifts in the trophic ecology of speckled trout resulting from interactions with yellow perch: an intra-guild predator-prey interaction. Trans. Amer. Fish. Soc. 138:1109-1122.

Curry, R.A., Brady, C. \& Morgan, G.E. (2003). Effects of recreational fishing on the population dynamics of lake dwelling brook trout. N. Amer. J. Fish. Manag. 23:35-47.

Davis, D.S. \& Brown S. (1996). Natural history of Nova Scotia: topics and habitats. Nimbus Publishing and Province of Nova Scotia. 518p.

Halfyard, E.A., MacMillan, J.L. \& Madden, R.J. (2008). Trout population parameters of select lakes within the southern Tangier Grand Lake Wilderness Area. Unpublished Data Report. Department of Agriculture and Fisheries, Inland Fisheries Division, P.O. Box 700, Pictou, Nova Scotia, B0K 1H0. 40p.

Hayes, F.R. \& Livingstone, D.A. (1955). The trout population in a Nova Scotia Lake as affected by habitable water, poisoning of the shallows and stocking. J. Fish. Res. Board. Can. 5:485-501.

Heggelin, A. (2008). Environmental and human factors affecting the population biology of Nova Scotia brook trout (Salvelinus fontinalis). Unpublished report. Nova Scotia Department of Fisheries and Aquaculture, Inland Fisheries Division, P.O. Box 700, Pictou, Nova Scotia, B0K 1H0. 36p.

Inglis, B. (1995). Angling laws of Nova Scotia (1868 to 1991). Published by author. Halifax, Nova Scotia, 20p.

MacMillan, J.L., Cassie, D., Marshall, T.J. \& Hinks, L. (2008). Population indices of brook trout (Salvelinus fontinalis), Atlantic salmon (Salmo salar), and salmonid competitors in relation to summer water temperature and habitat parameters in 100 streams in Nova Scotia. Can. Tech. Rep. Fish. Aqua. Sci. 2819:41p.

MacMillan, J.L. \& Madden, R.J. (2007). Angler effort and harvest of searun brook trout from a specially regulated estuary, Nova Scotia, Canada. In: Carline, R.F. and LoSapio, C., (ed). Sustaining trout in a changing world. Proceedings of Wild Trout 1X Symposium; West Yellowstone, Montana. p 186-192.

McNeill, A.J. (1995). An overview of smallmouth bass in Nova Scotia. N. Amer. J. Fish. Manag. 15: 680-687. 
Munro, C.L. \& MacMillan, J.L. (2012). Growth and overpopulation of yellow perch, and the apparent effect of increased competition on brook trout in Long Lake, Halifax County, Nova Scotia. Proc. N. S. Inst. Sci. 47(1):131-141.

Nova Scotia Department of Fisheries and Aquaculture. (1995). Sport fishing in Nova Scotia, 1995. Executive Summary. Nova Scotia Department of Fisheries and Aquaculture, Inland Fisheries Division, P.O. Box 700, Pictou, Nova Scotia, B0K 1H0.

Nova Scotia Department of Fisheries and Aquaculture. (2000). Sport fishing in Nova Scotia, 2000. Executive Summary. Nova Scotia Department of Fisheries and Aquaculture, Inland Fisheries Division, P.O. Box 700, Pictou, Nova Scotia, B0K 1H0.

Nova Scotia Department of Fisheries and Aquaculture. (2005). Nova Scotia Trout Management Plan, 2005-2010. Unpublished Report. Nova Scotia Department of Fisheries and Aquaculture, P.O. Box 700, Pictou, Nova Scotia, B0K 1H0.

Platts, W.S.\& Nelson,R.L.(1988). Fluctuations in trout populations and their implications for land-use evaluation. N.Amer.J.Fish.Manag. 8:333-345.

Post, J.R., Sullivan, M., Cox, S., Lester, N.P., Walters, C.J., Parkinson, E.A.,Paul,A.J.,Jackson,L.\& Shuter, B.J.(2002). Canada's recreational fisheries: The invisible collapse? Fisheries 27:6-13.

Post, J.R., Mushes, C., Paul, A., \& Sullivan, M. (2003). Assessment of alternative harvest regulations for sustaining recreational fisheries: Model development and application to bull trout. N. Amer. J. Fish. Manag. 23:22-34.

Power,G.(1980). The brook charr, Salvelinus fontinalis. In: Balon, E.K.(ed). Charrs: salmonid fishes of the genus Salvelinus. Dr. W. Junk Publishers, The Hague, The Netherlands, p 141-203.

Quinn, N.W., R. M. Korver, F. J. Hicks, B. P. Monroe, \& R. R. Hawkins. (1994). An empirical model of lentic brook trout. N. Amer. J. Fish. Man. 14:692-709.

Sabean, B. (1980). Creel census, Mooseland to Murchyville 1979. Wildlife Division, Nova Scotia Department of Lands and Forests, Kentville, Nova Scotia. Cat 80/172/100. 20p.

Smith,M.W.(1938).A preliminary account of the fish populations in certain Nova Scotia lakes. Trans. Amer. Fish. Soc. 67:178-183.

Smith, M.W. (1940). Fish Production in Trefry Lake, NS. Fish. Res. Board Can. Prog. Rep. 26:6-8. 